\title{
Storyworlds and the Semiotic Rules of Narrative Imagination: Peirce and Cassirer as a Starting Point for the Study of Literary World Experience
}

\author{
Bart Keunen
}

Ghent University, Blandijn 2, B-9000 Gent, Belgium

https://orcid.org/0000-0002-7049-2712

bart.keunen@ugent.be

\begin{abstract}
With the help of Peirce and Cassirer, this article embeds storyworld theory in a broader phenomenology of narrative imagination. A first step is the semiotic description of narrative imagination; storyworld elements come about through the laws that Peirce attributes to all semiotic processes (section 1). Besides, Peirce's insights are used to show that those elements significantly differ according to their phenomenological or epistemological nature. From this description of semiotic processes, a matrix of nine different signs will be derived (section 2) that correspond to nine distinct operations of imagination. The hypothesis is that it suffices to attribute a distinct function to each of the nine signs to adequately describe the experience of a storyworld.
\end{abstract}

Keywords: postclassical narratology / cognitive theory / semiotics / storyworld / imagination / Peirce, Charles Sanders / Cassirer, Ernst

If there is one element that distinguishes postclassical narratology from its structuralist and formalist predecessors, then it is the idea that stories give rise to mental models in the minds of their readers, hearers or viewers. Stories, says David Herman in Story Logic, derive their cultural relevance primarily from their capacity to turn experiences into storyworlds (9-22). By shifting the emphasis from the structure of the literary text to the study of storyworlds, twenty-first-century narratology realized a genuine paradigm shift (Bortolussi 2). Thus, the discipline established a connection with the phenomenological and philosophical approach to narratives that focused on the experience of reading (e.g., Iser, Ricoeur). 
The advantage of the study of 'worldmaking' is that it enables researchers to shift their attention from objective textual structures to the subjective cognitive processes of concrete readers, to "the procedures used to create and update worlds in narrative contexts" (Herman, Basic Elements 118-119). The storyworld has often been badly served by narratological tradition because everything that had to do with the referent of the text was put aside as "merely" the result of the reader's linguistic competences. Postclassical narratology, by contrast, points out that stories are constructed in such a way that they generate through targeted cues a mental image of the world that manifests "worldlikeness." David Herman makes in Basic Elements an argument "to slow down and deautomatize the rapid, apparently effortless interpretive processes involved in experiencing narrative worlds" (105) and patiently give thought to the process that he calls "worlding the story" (Herman, Storytelling x, 2).

My ambition with this contribution is to shift into an even lower gear than David Herman. Recent debates in narratology show that there is a great need for this. In a recent publication, Marco Caracciolo insists "on the processual and dynamic nature of worlding the story." The narratologist should pay more attention to how reading gives rise to a complex interaction between readers and the virtual world that surrounds them. He argues for an "enactivist" definition of worldliness focused on "a process of embodied exploration" (116). The process of slowing down proposed in my paper is in line with this perspective, but instead of referring to enactivist neo-phenomenology, I would like to retrace the problem to its epistemological origins (Gallagher 55, 101). By falling back to the sort of phenomenology that Charles Sanders Peirce and Ernst Cassirer were practicing, I will be able to dig deeper into more aspects of the process of 'worlding the story.'

Peirce offers an inspiring framework for the study of the storyworld phenomenon because he starts from the idea that "all this universe is perfused with signs" (The Essential Peirce EP 394). Whoever can describe the signs and the semiotic operations - the study of these was called 'Phenomenology' or 'Phaneroscopy' by Peirce (see Atkins)—will succeed in presenting "the ultimate analysis of all experiences" (Collected Papers CP 1.280). His project was given an extension in Gilles Deleuze's Cinéma, in which the corpus of images produced by film history was seen as a reservoir of varieties of the world experience. Although applying Deleuze's semiotics to the narrative world experience is not without problems- he often seems to mock Peirce's definitions and refuses to refer to the act of interpretation-the analysis offered here can be seen as a related project. Cassirer, for his part, is interesting because, more 
than Peirce (and a fortiori more than Deleuze), he emphasizes how the imagination processes control the construction and interpretation of such worlds. In the third part of his Philosophy of Symbolic Forms, Cassirer proposes to trace back cultural exploits of the humankind to a "phenomenology of knowledge" and to describe for each of the many cultural forms how they are aimed at creating a world sui generis (10).

\section{The imaginator and the imaginative signs}

The postclassical paradigm shift was fueled by insights from the discourse processing theory that gained increasing popularity in the linguistics, cognitivist psychology and computer science of the 70s. Reading a literary text, it was said, is accompanied by a mental operation that draws from the text a "referential representation" (Bortolussi 17) or a "mental model" (Herman, Basic Elements 106). From this perspective, narrative artifacts (texts, films, etc.) are interpreted as "blueprints for the creation and modification of such mentally configured storyworlds" (107). Important in this process of worldmaking is that readers are ascribed the capacity to connect the blueprint with their prior knowledge and expectations. Defining this prior knowledge is based on "what Minsky called frames, or structures for representing and remembering stereotypical situations (e.g., being in a living room or a store)" (106). Frames constitute a cognitive construction possessed by every competent reader. They are, after all, the common schemata of memory with which readers organize their knowledge of the world in everyday experience (they are "for Minsky a means for organizing knowledge of the world into discrete, manageable chunks" 106). Narrative artifacts contain cues that ensure the activation of the readers' available prior knowledge and the transformation into schematized chunks of information, into "mental models" or "referential representations."

With the help of Peirce, this innovation can be defined more precisely. Considered semiotically, the worldlikeness of the story is the result of a triangular relationship. A sign is, by definition, threefold: a sign-vehicle (or representamen) stands for an object and produces a mental image (or interpretant) with a receiver (Peirce, EP 2 13). All three are activated in the process of reading. In the readers' brain, (1) mental images ("referential representations") arise that can be regarded as an equivalent of the interpretant element. They are the result of linking the (2) verbal signs (the words, the representamen) to the (3) prior knowledge of the reader (the frames, the object that the sign stands for). 
Although "re-engagement with the referential, world-creating potential or narrative" (Herman 106) is a decisive step for the investigation of narrative imagination, the cognitivist principle also poses problems. What is particularly problematic, is that discourse processing theories teach little about the way in which those mental models are perceived by readers, and that much remains unclear about the type of prior knowledge or the precise nature of the cognitive operations that are necessary to make those models life-like and world-like. This problem can be avoided if the semiotic analysis is detached from the verbal signs and focus is shifted to the schematic representations, the mental models themselves. In this way, the problem of the act of reading is moved to the activity of imagination. The semiotic analysis thus receives a new, quasi-Aristotelian study object; it turns into a kind of "phantasmalogy" that studies the processing of mental images (Aristotles "phantasmata," see Liao) through operations of imagination. In the act of reading readers are not only beings that interpret words, but also 'explorers' that examine the schematized information (the result of the reading) and thereby seek the additional meaning this possesses for them. According to Peirce's semiotics, this is completely sound: any interpretation of a sign (in this case the schematized representation - the interpretant - evoked by verbal signs) can in itself act as a sign for a new interpretative process (CP 2.228, 8.191; Liszka 33).

In the course of this paper, I would like to take referential representations as autonomous signs that function in the same way as verbal signs. I will consider them as imaginative signs (representamen) that are interpreted (interpretant) by connecting elements of prior knowledge (object). I would call the recipient imaginator, in order to avoid confusion with the experience of reading strictu sensu. In my view, a detailed description of the processes of the imagination of such an imaginator can lead to a better insight into the specific world experience that readers undergo during the act of reading.

\section{The elements of the imaginative sign}

To make my argument concrete, I now introduce (in a slightly abbreviated version) a short text from Charles Baudelaire's Le Spleen de Paris:

Under a wide gray sky, on a great dusty plain with neither pathways nor grass nor thistles nor nettles, I came upon a number of men who walked along bent over. Each of them carried on his back an enormous Chimera ... I questioned one of the men, and I asked him where they were going in this condition. $\mathrm{He}$ 
replied that he didn't know at all, neither he nor the others; but that apparently they were all headed somewhere, as they were all driven by an irresistible need to walk. A curious thing worth noting: None of these travelers seemed to be troubled by the ferocious beast hanging around his neck and attached to his back; it was as if each considered it a part of himself. All these weary, serious faces revealed no sense of despair; under the splenetic dome of the sky, feet plunged into a dusty soil as desolate as the sky, they marched onward with the resigned look of those condemned to eternal hope. And the whole retinue passed by me, soon sinking into the hazy horizon. And for a few seconds I stubbornly tried to understand this mystery; but soon an irresistible Indifference crashed down upon me, and I was more heavily burdened than they were by their crushing Chimeras. (12)

Baudelaire's text brings up schematic representations of a celestial dome, a desert-like plain, and walking characters that carry a heavy burden while journeying through the desert. Besides, equally schematic images are created that relate to the storyteller's interaction with the characters (he addresses one of them). Moreover, we occasionally get a picture of a storyteller who speaks to the reader in order to express his reactions to the event. Each of those referential representations can be analyzed semiotically. They display the characteristics of an imaginative sign: a representamen that stands for an object and evokes an interpretant.

The object with which the imaginator associates the representamen is — in the same way as with the verbal sign described above-an element from his prior knowledge, but this time enriched by imagination (the imaginator's memories of similar desert-like settings, knowledge about social interactions or psychological reactions). The semiotic object does what every semiotic object does, according to Peirce: it "determines" the representamen and defines the limits within which the sign acquires meaning (CP 6.347). In this sense, the semiotic object is the engine that drives processes of "worlding the story," because it provides the material with which the imaginator "feeds" the sign and which gives it experiential potential.

The second element that plays a role in the construction of the storyworld is the cornerstone of the interpretation: the interpretant. Peirce gaged this concept to emphasize that something is added in the act of interpreting a sign (and its relationship to an object), to wit: a new mental sign (EP 2 493-494, CP 5.594). This usually involves the "implicit words" that the imaginator uses to shape the world of imagination (e.g., "the Chimera carriers have a miserable destiny"). In addition, the interpretant can also be a feeling (CP 4.536, 8.369), such 
as pity or fear - to name the two emotions that dominate the storyworld of Baudelaire (and are linked to classical tragedy, according to Aristotle's Poetics).

\section{Epistemological accents concerning imaginative signs}

The representamen-object-interpretant triad is an interesting tool in describing how narrative imagination works. Yet the semiotic process says little about the diversity of operations of imagination that are needed to construct a storyworld. In order to map out this diversity, one must have insight into the contexts of prior knowledge that play a role in the processing of the sign. In addition, a theoretical framework is needed that distinguishes types of epistemic operations. For this sort of problem, Peirce's semiotic frame of thought offers a solution as well (Liszka 43). One of his most inspiring findings is the proposition that a sign can privilege specific aspects and anesthetize other aspects. In the further course of this paper, I will develop this insight and, following Peirce, distinguish nine types of signs. These nine types are established by taking into account two types of emphases: on the one hand, the emphases that result from the diversity of epistemic modes, and, on the other hand, the accents for which the diversity of experiential domains (contexts of prior knowledge) is responsible. Both emphases probably have their basis in the workings of the human brain and the specific interaction it maintains with its Umwelt, but regarding this matter, Peirce makes no claims whatsoever, unlike Cassirer who refers in Essay on Man to Jacob von Uexküll's biological model (41).

According to Peirce, diversity in the field of the epistemic mode is due to the power a sign possesses to give a stronger accent to one of its three components. Depending on this emphasis, a specific epistemic mode is privileged, thereby making it possible to talk about signs that privilege, respectively, the "mode of being/presentation," the "mode of representation/reference to the object" or signs that favor the "mode of interpretation/reference to the interpretant." Peirce has a logical explanation for this distinction: the brain of the receiver is confronted, respectively, with one, two or three elements - with firstness, secondness or thirdness.

Some of the imaginative signs in 'Everybody their Chimera' (e.g., aridity, heaviness, the indifferent face of the walkers) lend themselves perfectly to highlight the "firstnesses," the "mode of being" of the sign. The imaginator experiences them as if they are a reality and personally 
feels the atmosphere of the desert trip. They hardly require any work on the part of the brain because sign and semiotic object dissolve into each other, because, in principle, the imaginator has no conscious awareness of the prior knowledge he uses. Moreover, there is no need to examine the relationship that the sign maintains with prior knowledge in order to also anesthetize the interpretant.

In the second epistemic mode, the relationship between sign and object is explicitly put in the forefront. The receiver's attention is focused on the connection of two elements so that the epistemic mode can be characterized as "secondness." When reading Baudelaire's text, this occurs when the imaginator emphatically connects an imaginative sign with an object of memory (the landscape reminds him of a desert) or with prior knowledge concerning causality (the scenes in the text are arranged according to a pattern that follows the laws of empirical causality).

Finally, the third epistemic mode requires the greatest intellectual effort because there are three elements involved. The receiver draws conclusions from the relationship between a sign and its object (Peirce CP 8.314). In the context of narrative imagination, one must think of signs that tempt the imaginator to connect subjective connotations with the imaginative sign. Baudelaire's text occasionally leads to a state of consciousness in which a subjective interpretation (the interpretant) is brought in the forefront: the imaginator feels pity, arrives at the conclusion that the narrator displays psychological reactions and is not insensitive to the hopelessness of the situation.

\section{Phenomenological accents concerning imaginative signs}

These three groups already illustrate the richness of the imaginative world of experience. However, in a later stage of his career, Peirce concluded that there is a second way in which signs can differ from each other. More specifically, the diversity of contexts of experience or prior knowledge brings out different and equally important accents in a sign. In the years following the penultimate turn of the century, Peirce felt the need to further expand his typology by taking into account the 'phenomenological nature' of the sign. Indeed, also with respect to the phenomenology of experience, a distinction can be made between "firstnesses," "secondnesses" and "thirdnesses." Peirce names these experiential contexts utilizing the concepts of "quality," "brute reaction" and "mediation." Gilles Deleuze beautifully illustrates in his Cinema books 
what exactly is meant by Peirce when he isolates and interprets images of affection, action and relation in the work of classical filmmakers.

In the imaginative signs evoked by Baudelaire's fictional world, one also recognizes these phenomenological accents. In order to find clues of these differences, it suffices to give a moment's thought to the experience of reading. One could say that the imaginator is simultaneously present in three worlds while reading. The least complex world or context of experience comes up for discussion when the imaginator withdraws into the personal private world and-guided by what von Uexküll would call the "receptor system"-focuses on those specific imaginative signs that have a direct aesthetic effect. In Baudelaire's text, this concerns signs indicating that the sky is gray and splenetic, the plain solid, dusty, empty and desolate or that ferocious, powerful chimeras weigh down the characters. The text, through those specific images, seduces the imaginator to believe in the existence of sensory qualities, both visual and tactile, and also a little bit kinesthetic.

Typical of this aspect of the reading experience is that the imaginator limits himself to the context of the "immediate present." He undergoes the impressions in a spontaneous, almost scattered way. Moreover, his reactions are 'physical' in a certain sense: he submits himself to quasisensory impressions, to a stream of recognizable images and to the connotations (emotions or ideas) that they evoke in him. Out of this way of perceiving, the world in which the imaginator finds himself becomes a vibrant and life-like world of experience. The sign takes him to a closed, monadic world of "firstnesses only." The immediate 'lyrical' effect that stories often exert corresponds to the imagination in the narrow sense: the experience of "images" that have a qualitative similarity to images from the arsenal of prior knowledge (Johansen 30). The lyrical effects of imagination were often neglected in narratology. Postclassical theorists put this world of experience back on the narratological agenda. "Interpreters of narrative," says Herman, "do not merely reconstruct a sequence of events and a set of existents but imaginatively (emotionally, viscerally) inhabit a world in which ... things matter, agitate, exalt, repulse" (Basic Elements 119).

Coinciding with the first experiential context, a second context urges itself upon the imaginator. The imaginator encounters resistance from the imagination material - it cannot be entirely reduced to what she or he would like to make of it in their "lyrical" omnipotence. This resistance can be traced back to the temporal dynamics in the story. Minimal changes in the imagination material give the story a theatrical allure. The group of people is moving in a desert plane; the narrator 
takes the initiative to go talk to someone; we see the people march with determination, and the action ends with a narrator who says he feels more discouraged than the characters he observes. The imaginator who is caught up in this type of "resisting" and dynamic world is-led by what von Uexküll would call the "effector system" — actively creating connections between the changed situation and the situation before (consequence-cause). Moreover, he connects the situation with expected changes (action-response).

When the imaginator interrelates things, the exclusive bond with the immediate present is broken, because she or he is also concerned with the past, while at the same time anticipating the future. The focus on sequentiality and especially on the causal relations pervading the material of imagination - a well-known research topic in narratological studies-leads to a completely different type of experience than what was previously seen. The relations of dramatic tension are connected to a different type of object. It is not so much the idiosyncratic and monadic image that the imaginator immediately associates with the sign, but rather the memory of a virtual image that is causally associated with the imaginative sign. Because of the changes in the world of Baudelaire he or she is forced to expand the first world to a second world that, as it were, adds a second layer to it. Thus, he or she experiences two phenomena at the same time: on the one hand, the firstness of the lyrical effects and, on the other hand, the "dramatic" relationship between two units, each of them possessing its own firstness.

The third world that occurs during the experience of reading arises when the imaginator uses his imaginative capacity to link the referential representations to "solidified" knowledge when he relies on external corpora of knowledge. Solidified knowledge concerns information about various forms of what Peirce calls "regularities" (Atkins 148), that is, information about fixed relationships between elements of information with which the imaginator becomes acquainted in the course of his life (personal experience, knowledge out of books, stereotyped image constellations - everything that is law-like and "carved in stone"). A good example is the knowledge about symbolist conventions, such as the idea of allegory and the theory of correspondences. This knowledge is indispensable for fully experiencing Baudelaire's text. In this way, the image of the "splenetic dome of the sky" only has a melancholic effect when the imaginator brings to bear knowledge about the concept of 'spleen' and the allegorical connection between soul and world. In this operation of imagination, the imaginator no longer focuses on the qualities in the storyworld, and neither on the dynamics of the events. 
Instead, he focuses on the implicit evaluations that he believes to recognize in the storyworld. These implicit evaluations relate to all kinds of intellectual frames of reference (e.g., genre conventions, which are often neglected by neurobiological research on imagination, see Richardson 234) and provoke a kind of intertextual operation, since this type of experience is entirely based on "texts" as intermediary bodies. It goes without saying that the two previous worlds are indispensable in generating such an experience. The extra knowledge only has an effect when it is applied to lyrical and dramatic phenomena. In other words, as Peirce repeatedly states, thirdness implies firstness and secondness.

\section{The nine imaginative operations that construct a storyworld}

On the basis of the epistemological and phenomenological types of privilege, Peirce arrives at a list of nine classes of signs, arranged in the matrix below. The scheme is complemented by some of my own terms, which were already informally introduced (lyrical, dramatic and intellectual) or which anticipate the epistemic properties of narrative imagination that were inspired by Ernst Cassirer and are discussed in this section.

\begin{tabular}{|l|l|l|l|}
\hline World Experience & $\begin{array}{l}\text { Firstness } \\
\text { Quality } \\
\text { Lyrical }\end{array}$ & $\begin{array}{l}\text { Secondness } \\
\text { Brute reaction } \\
\text { Dramatic }\end{array}$ & $\begin{array}{l}\text { Thirdness } \\
\text { Mediation } \\
\text { Intellectual }\end{array}$ \\
\hline $\begin{array}{l}\text { Firstness } \\
\text { Mode of Being } \\
\text { Oneiric Mode }\end{array}$ & $\begin{array}{l}\text { Qualisign } \\
\text { Quality that is a } \\
\text { Sign }\end{array}$ & $\begin{array}{l}\text { Sinsign } \\
\text { Event that is a Sign }\end{array}$ & $\begin{array}{l}\text { Legisign } \\
\text { General Type that } \\
\text { is a Sign }\end{array}$ \\
\hline $\begin{array}{l}\text { Secondness } \\
\text { Mode of Reference } \\
\text { to Object } \\
\text { Constructivist } \\
\text { Mode }\end{array}$ & $\begin{array}{l}\text { Icon } \\
\text { Qualitative } \\
\text { Relation of Sign } \\
\text { and Object }\end{array}$ & $\begin{array}{l}\text { Index } \\
\text { Genuine Relation } \\
\text { of Sign and Object }\end{array}$ & $\begin{array}{l}\text { Symbol } \\
\text { Abstract Relation } \\
\text { of } \\
\text { Sign and Object }\end{array}$ \\
\hline $\begin{array}{l}\text { Thirdness } \\
\text { Mode of Reference } \\
\text { to Interpretant } \\
\text { Hermeneutic Mode }\end{array}$ & $\begin{array}{l}\text { Rheme/Seme } \\
\text { General Interpre- } \\
\text { tation of Some } \\
\text { Possible Object }\end{array}$ & $\begin{array}{l}\text { Specific Interpre- } \\
\text { tation of Actual } \\
\text { Properties of } \\
\text { Object }\end{array}$ & $\begin{array}{l}\text { Argument } \\
\text { Logical Interpreta- }\end{array}$ \\
\hline tion Judgment \\
\hline
\end{tabular}

Peirce had a clear philosophical intention with his matrix of nine classes of signs, namely "to unravel the tangled skein [of] all that appears in 
any sense and wind it into distinct forms" (CP 1.280). If it is true what postclassical narratology claims, that narrative experience is based on worldlikeness, then we should evidently also find the nine signs in the narrative imagination. In what follows, I will distinguish nine possible aspects of the storyworld. Although these are arbitrarily activated in the actual experience of reading and can often occur in combinations, they may positively be seen as distinct signals that trigger the process of "worlding the story."

The semiotic matrix, which I discuss in detail below, contains signs that considerably deviate from the examples given by Peirce in his discussion of the classes of signs. Peirce was not, or hardly ever, concerned with artistic signs. Yet from his remarks about imagination (Peirce CP 7.646; see Barrena, Andacht, Johansen) it can be deduced that my overview of imaginary signs corresponds to his method of working. Other thinkers also give clues in connection with operations of imagination that are nicely attuned to Peirce's analysis. Below, I will mobilize these authors to reinforce my hypothesis about the nature of narrative imagination. On the one hand, I will point out the similarity of five of the signs to the five codes distinguished by Roland Barthes in $S / Z$. For Barthes, the five textual codes correspond with totally different ways of interpretation; they are different voices in the polyphony of reading (Barthes 19, 30). In the following, I will relate them to types of imagination processes we discovered through Peirce's semiotics.

On the other hand, significant similarity exists between Peirce's three types of phenomenological experience and the triad used by Ernst Cassirer-relying on some of Goethe's maxims and Uexküll-in his posthumously published The Metaphysics of Symbolic Forms (Krois). The Peircean epistemic modes also play a major role in his work. In the first three parts of his magnum opus, he continually relies on an epistemological triad that corresponds in some aspects to that of Peirce (Ausdruck or Expression, Darstellung or Representation and Reine Bedeutung or Signification).

\section{Variations of the oneiric mode}

For a proper understanding of the first epistemic mode within narrative imagination, we need to bring to mind the experience of dreaming. In dreams, we experience "the absence of the constraints upon thought characteristic of waking imagination" (Walsh). Instead, we merge with the "firstness" of the oneiric signs and are affected by the mirages that 
pop up "before our eyes." In Cassirer's view, dream images are exponents of the most elementary epistemic operation of which the brain is capable. In The Metaphysics of Symbolic Forms, Cassirer refers to Ludwig Klages's dream theory, which very clearly shows to what extent dreaming subjects produce knowledge in their own way (23-32). Analogous to Peirce's idea of "firstness," the essence of oneiric knowledge, he states in Mythical Thought, is that it does not distinguish between "image and thing, the sign and what it designates" (72), it entails an unmediated "authentic presence" (68).

In the oneiric mode of knowledge, the attention is completely absorbed by the presence of the sign. Typical of signs conceived in their firstness - in this resides their affinity to the dream-is that they do not refer to an object, but rather are the object: a qualisign is the quality, a sinsign is the event, and the legisign is the general type. Here, one can bring to mind the phenomenon called "immersion" in narratology (Gerrig, Ryan, Burke) or neurobiological observations about the functioning of mirror neurons (Lakoff 19). Narratological research, however, does not sufficiently respect the phenomenological differences between the oneiric signs of imagination (quality, reaction, mediation). These are related to the diversity of prior knowledge that is mobilized by the imaginator with the purpose of giving meaning to the signs.

A qualisign belongs in the private world of the imaginator. Above, some examples were given of signs that shape Baudelaire's prose poem and provide a specific "quality of feeling" (Peirce CP 1.303). The affects evoked by words such as barren and empty, or the sense of gravity that we associate with the "cumbersome" Chimera are examples of lyricaloneiric images. The way in which the rhythm of the text affects the imaginator can also be seen as a form of immersive knowledge. The slow pace of the first few sentences or Baudelaire's story already anticipates the way the chimera pushes down on the heads and the backs of these ambulating characters.

The sinsigns include all kinds of changes that involve chains of images confronting the imaginator with a response unit (the prefix sin indicates "unity"). Peirce primarily observes the experience of sinsigns in the experiential context of empirical facts, but this type of phenomenon also occurs within narrative imagination. In dreams and stories, the causal chain of events is experienced in an immediate manner (e.g., dangerous situations disappear through the actions of a character or, on the contrary, are worsened by frightening characters). The liveliness of the dream and the experience of narrative actions are most strongly reflected in the imagination of characters. As a collection of proper- 
ties, characters give rise to an experience of firstness, but as instances of action, they generate the experience of secondness. As goal-directed instances, they are the ideal lubricant to give shape to the dramatic experience of time. This hybridity in the imagination of characterswhich was already observed by Aristotle (pt. 6) —is implicitly reflected in narratological research (Burke 231-232), but can gain more relevance with a Peircean sense of nuance.

The legisigns of narrative imagination also fall under the oneiric mode of knowledge. This is because they imply a spontaneous pattern of reaction in which the mediating knowledge item (e.g., the correspondence device of the symbolists) is applied automatically. This somewhat resembles the absence of reflection on the precise meaning of a monster appearing in a dream: it is nothing more than the incarnation of "danger" and "evil." Postclassical narratology has also made many contributions concerning legisigns, especially in the field of the study of characters (Jannidis).

\section{Variations of the constructivist mode}

There is a common-sense belief that equates imagination with dreaming (Gottschall 28). Imagination is said to involve fantasy, creative reproduction of the empirical reality in the brain. This view of imagination as a capacity for reproduction is often central to experimental psychology (cf. pictorialism) and the philosophy of imagination (Gilbert Ryle, Jean-Paul Sartre). Paul Ricoeur ("Function" 118-123) has rightly pointed out the reductionist nature of these theories of imagination. Basing his view on Kant, he states that we must sharply demarcate reproductive imagination from a more complex operation of thought: productive imagination. Imagination, after all, is also, and above all, the ability to order, to contemplate from a distance, and to upgrade the world experience — as we do in dream recall (Dennett 132-134) — to a constructed whole.

A theoretical foundation for this thesis can be found in Cassirer's work. When discussing the second type of object construction, he refers to the constructed character of human perception (or, in the Kantian mode of expression, "intuition"). "In the field of intuition and the pure "representative function," it is necessary, Cassirer says, to invoke "the aid of the 'productive imagination' at every step" (Phenomenology 306). In the Essay on Man, Cassirer further develops his view of productive imagination and explicitly refers to that specific epistemic mode that 
is typical of works of art. The artistic imagination, he says, is indeed related to other forms of simulation-based knowledge such as dream and play: "In play we have to do with simulated images which may become so vivid and impressive as to be taken for realities" (209). Dream and play, however, are purely expressive forms of knowledge that do not yet fully unfold the constructivist power of imagination. This only happens when an artistic form is imposed on the phenomena: "In play we merely rearrange and redistribute the materials given to sense perception. Art is constructive and creative in another and a deeper sense" (209).

The Kantian idea of productive imagination, as elaborated by Ricoeur and Cassirer, returns in the three signs that Peirce associates with the representational mode of knowledge: icons, indexes and symbols. Because they favor the relationship between representamen and object, with these three operations, an element emerges that is often central to theories of reading, to wit, the conception of reading as the creative handling of "information gaps" (Iser 92, 166-167; Miall 261). As will become clear, these gaps can be described more accurately as a three-fold phenomenon employing Peirce's phenomenological categories.

The constructivist sign that belongs in the lyrical context of experience, the icon, requires completion by way of "personal" information. Ryan calls this the principle of minimal departure, which states that "when readers construct fictional worlds, they fill in the gaps in the text by assuming the similarity of the fictional worlds to their own experiential reality" (Ryan, Possible Worlds 447). The representamen (a schematic representation, such as the script "desert trip") is fed by the imaginator with items from a corpus of images of memory. Thanks to the connection he makes between the representamen and the (determining) object, the imaginator ensures that the schematic representation will display similarities to desert images from his memory.

Icons ensure that the storyworld becomes a "trusted environment"; indexes, by contrast, work with interactions and are placed under the constellation of the recalcitrant and the variable. They give signals to the imaginator to represent the changes as a "causal-chronological whole" (Herman, Storytelling 37). Characters, for example, are recognized as having a Greimasian "actantial function" and are organized in accordance with a logic of cause-effect or action-reaction. When, at the end of Baudelaire's text, the narrator refers to "an irresistible Indifference crashed down upon me," then this information raises the question about the cause of this emotion, and therefore about the depressing events that precede it - to a certain extent, it turns the walkers into antagonists. This example nicely illustrates the way in which an indexi- 
cal operation of imagination contributes to the construction of a storyworld: the information gaps are not so much related to the properties of its elements (as in the case of iconicity), as they are to the causal relations between the imaginative signs. The temporal logic, or the sequentiality of the elements in the storyworld, occupies the central place. This temporal relation can go in all directions because sometimes it is an object that must be seen as a consequence, sometimes it is an object that constitutes the cause of the phenomenon. For this reason, indexes are at the basis of "curiosity, surprise and suspense," the universals of narrative temporality discovered by Sternberg (517-518). They also hold a central position in Paul Ricoeur's masterful Time and Narrative. The phenomenon that he calls "emplotment" — which he explicitly connects with the operations of productive imagination (68) — can be seen as an interpretative cognitive construction based on the indexical relationship between imaginative signs and their causes or effects.

Finally, the constructivist mode of knowledge also has a variant that is realized with the help of thirds. Barthes uses the term "symbolic code" for such operations of imagination. With a little goodwill, these can be seen to correspond to what Peirce calls symbols. In $S / Z$, Barthes gives the example of the symbol of castration in Balzac's story. In this, he acts as an imaginator who uses the psychoanalytic view of sexuality to solve a problem in the plot (a "second") or to increase the recognizable nature of the story elements ("firsts"). The distinguishing characteristic of such signs is that they refer to a system of judgments, that the imaginator recognizes a theoretical relevance in them. They invite the imaginator to search the storyworld for recurring images and to link these to specific conventions. This operation of ordering gives rise to a semantic framework in the storyworld, a structure of semantic clusters that refer to a view or belief and that can subsequently be combined with each other (for example, to generate the oppositions that "Greimasian" structural semantics discuss). The result of a symbolic operation of imagination (the interpretant of a symbol-sign) corresponds to what is traditionally understood by "themes."

\section{Variations of the hermeneutic mode}

The hermeneutic mode of knowledge may be regarded as the closing piece of the narrative world experience. Signals that explicitly relate to an interpretation, that elicit a conscious reaction from the imaginator, fall under the classes of rheme, dicisign and argument. Typical of such 
signs is that they entice the imaginator into making a judgment and encourage him to reflect. To use Cassirer's words, they are "brought to light by conscious intellectual effort" (Phenomenology 283). Cassirer sees this epistemic mode explicitly as an intensified form of productive imagination (306). His definition comes very close to what Peirce means by "mode of interpretation" because in the third type of knowledge, the emphasis is laid explicitly on the interpretant of the sign, on those propositions that pass judgment on a state of affairs.

Evidently, icons, indexes and symbols also have an interpretant, but Peirce (in this followed by Deleuze) regards these as a kind of residual product; it only concerns a "conclusion" in relation to a quality, a reaction or a mediation. In the case of rhemes, dicisigns and arguments, interpretation is brought into prominence. Following Roland Barthes, the hermeneutic mode of knowledge could be called the "realm of truth." When he speaks of the semic and the hermeneutic code, Barthes refers to the judgments concerning "truth" readers make while reading (e.g., 61-62, 75-76, 171). Here, however, the truth cannot be understood as empirically tested truth. Rather, judgments in fiction deal with the truth and credibility of the storyworld. One could say that such judgments are beyond the reach of the storyworld itself, yet it is undoubtedly so that they are an essential component of the narrative world experience. Such in any case, was Mark Twain's understanding when he reportedly claimed that "the only difference between reality and fiction is that fiction needs to be credible."

The first kind of signal that invites credibility to be assessed are the signs that Peirce calls rheme (alternately called seme; CP 4.538). Statements such as "under the splenetic dome of the sky, feet plunged into a dusty soil as desolate as the sky, they marched onward" force the imaginator to assess the desert and the walkers as depressing, in order to let the qualitative similarity between the sign of imagination (the frame "desert trip") and the object of memory (the qualitative properties of deserts and walks under harsh circumstances) end in the idea and the feeling of "what a depressing state of affairs." In this sense, the rhemes are signals that are responsible for an important aspect of the aesthetics of stories: they produce, among other things, the tragic emotions that Aristotle considers crucial for a successful aesthetic experience. One could say that the evaluative act "contaminates" the image with qualitative connotations (Baudelaire's characters provoke the fear of social isolation or a feeling of exhaustion). The interpretant of the rheme thus generates a surplus of meaning that is added to the storyworld. Roland Barthes classes such connotations under the name "semic code" and 
calls them "impressionistic": the semic code "plays with the distribution of a discontinuity (thus creating a character's 'personality')" (22).

The second type of evaluative connotations (the class that Peirce calls dicisigns) does not concern qualitative evaluations, but rather the dynamics of events. When the narrator talks about faces that reveal "no sense of despair," that have "the resigned look of those condemned to eternal hope," and when he talks about characters "driven by an irresistible need to walk," then he forces the imaginator to render a judgment about the causal coherence of the story. The faces are evaluated on the basis of their quality of reaction (they respond to the desire to move forward and not to the heavy burden under which they suffer), the characters on the basis of the psychological motivation that explains their behavior. Statements made by the narrator, in which he assesses himself (e.g., "an irresistible Indifference crashed down upon me") automatically lead to an opinion at the side of the imaginator, because the narrator himself connects his feelings with the situation they cause.

The assessment of causal relations between scenes or images, as in the discussed example, often boils down to assessing the credibility of the behavior and the psychological responses of the characters. Narratology studies such judgments under the name of "theory of mind" or "literary mindreading" (Palmer, Zunshine, Mar and Oatley). Central to judgments about causal relations concerning the psychology of the characters is their credibility - they belong to what Barthes called the "Voice of Truth" (the hermeneutic code). The imaginator should ask himself whether lonely walks in the desert are accompanied by negative feelings and whether it is credible that someone looks down on people who respond to them with positive feelings. If the imaginator attaches faith to this state of affairs, the scene can be used to perform an additional operation of imagination within the third experiential context (he can consider the depressing desert journey as a symbol when he recognizes in it the expression of the theme of hope or hopelessness).

A third type of sign that is related to the truth of the fictional world, shows similarities to what Peirce calls "argument". If an imaginator reads Baudelaire's text through the lens or Walter Benjamin's theory of modernity, she or he is using imagination to see the text as an illustration of a critique of phantasmagoria and hence as an implicit evaluation of contemporary capitalism. He or she will use the semantic tension between hopelessness and naive hope to come to an understanding of the sad fate of the citizen in the capitalist metropolis. When the imaginator uses an intertextual framework of judgments (Marxist ideology criticism) as a mediator between a specific imaginative sign (the image 
of "the resigned look of those condemned to eternal hope") and the final interpretation, he enters the domain of theoretical assessment. As in the Benjamin example, it can give rise to a series of neo-Marxist associations that build on the implicit judgment of the narrator, whether alleged or not, whether in the form of hineininterpretierung or based on evidence.

\section{Conclusion: About the usefulness and disadvantage of a semiotic matrix of imagination}

To conclude, I would like to point out that the presented semiotic matrix can and will be more than a description of the processes of "worlding the story." The matrix is bound to be useful as a heuristic tool for (1) assessing practices from literary criticism, (2) identifying gaps in narratological research, and (3) facilitating comparative research in the field of intermediality.

(1) Taking the different forms displayed by narrative imagination as a starting point, one could describe three caricatures of readers that are all too common in the world of literary criticism. A first clichéd figure is the naive reader who reads "from the gut" and therefore only has eyes for firstnesses (both in terms of the context of experience and of the modes of knowledge). The non-academic or dilettante reviewer, a second caricature, is involved in "reading for the plot" and has an eye for the secondnesses, the constructivist elements and the dramatic elements. University literary criticism has understood Barthes's wise advice - to wit, that it is best not to limit literary experience to the proairetic code (30) — and, by contrast, focuses primarily on the thirdnesses of the narrative world experience-both on the hermeneutic mode of knowledge and on the intellectual field of experience. These three caricatures can be seen as reductionist readers to which the polyphony of reading is lost. Conversely, one can say that readers who activate all elements of the semiotic matrix come closer to what can be called a rich narrative imagination.

(2)The matrix is a useful tool for mapping trends in narratological research. As it turns out, a one-sided focus on sequentiality is not only a fault that characterized structuralist narratology. Indeed, it often looms up in postclassical narratology, as if it were the return of the repressed. The reason for this is perhaps the desire to connect more closely with the experience of a concrete reader - the reader who meets the profile associated above with "reading for the plot." The second generation 
of cognitivism-inspired narratologists tries to remedy this by paying more attention to the oneiric mode of knowledge and by focusing more strongly on epistemological operations that concern the lyrical domain of experience. Other theorists attempt to fill the gaps in current narratological research pertaining to the intellectual domain (e.g., Herman and Vervaeck, Nünning).

(3) The matrix can finally be a heuristic instrument for intermedial comparative research. On the basis of the "matrix of imagination," it can be concluded that the nature of the representamen is responsible for the creation of distinct semiotic processes. The oneiric epistemic mode differs entirely depending on the media used. Verbal narratives work with referential representations that must be distilled from verbal signs, and these are merely schematic representations. In the case of cinematic images, the referential representation is anything but schematic, in such a way that the operations of imagination can be performed directly, as Deleuze's descriptions show (it is no accident that he calls perception images instances of 0 -ness). As far as their graphic aspect is concerned, graphic novels, for their part, work with imaginative signs that are a representation of schematic representations. Nevertheless, as Deleuze's film semiotics shows, the operations of thought return in more or less the same proportions for literature, film and comics.

I would like to emphasize that the research of narrative worldmaking also brings about many limitations. Mapping operations of imagination does not relieve the narratologist of the obligation to keep a keen eye on "the design of the blueprint itself - complexities creating additional layers of mediation in the relationship between narrative and storyworld" (Herman Basic Elements 107) or on the functioning of narrativity in a broader cultural context (e.g., the ability of stories to break expectations, or to be used in everyday contexts as instruments of "sense making," cf. Herman Storytelling 263-310). Nevertheless, the study of the imaginative operations seems to me to be of fundamental importance, perhaps even a priority. "First things first." For a Peircean semiotic, this expression means: first, to examine the worldlikeness (iconicity, firstness); next, to scrutinize the relationship with textual mechanisms (indexicality, secondness); finally, to investigate cultural relevance (symbolicity, thirdness). 


\section{WORKS CITED}

Andacht, Fernando. "Those Powerful Materialized Dreams: Peirce on Icons and the Human Imagination.” The American Journal of Semiotics 17.3 (2001): 91-116.

Aristotle. Poetics. Trans. S. H. Butcher. London: Macmillan, 1929. The Internet Classics Archive. Web. 12 Dec. 2019.

Atkins, Richard Kenneth. Charles Sanders Peirce's Phenomenology: Analysis and Consciousness. Oxford: Oxford U.P., 2018.

Barrena, Sara. "Reason and Imagination in Charles S. Peirce." European Journal of Pragmatism and American Philosophy V-1 (2013). Web. 12 Dec. 2019.

Barthes, Roland. S/Z. Trans. Richard Miller. Malden, MA: Blackwell, 1974.

Baudelaire, Charles. Paris Spleen. Trans. Raymond N. MacKenzie. Indianapolis: Hackett Publishing, 2008.

Bortolussi, Marisa, and Peter Dixon. Psychonarratology: Foundations for the Empirical Study of Literary Response. Cambridge: Cambridge U.P., 2003.

Burke, Michael. Literary Reading, Cognition and Emotion: An Exploration of the Oceanic Mind. New York: Routledge, 2011.

Caracciolo, Marco. "Ungrounding Fictional Worlds: An Enactivist Perspective on the 'Worldlikeness' of Fiction." Possible Worlds Theory and Contemporary Narratology. Ed. Alice Bell and Marie-Laure Ryan. Lincoln: U. of Nebraska P., 2019.113-131.

Cassirer, Ernst. Essay on Man: An Introduction to a Philosophy of Human Culture. New York: Doubleday, 1944.

Cassirer, Ernst. The Philosophy of Symbolic Forms. 2 (Mythical Thought). 3 (The Phenomenology of Knowledge). 4 (The Metaphysics of Symbolic Forms). New Haven: Yale U.P., 1955, 1957, 1996.

Deleuze, Gilles. Cinéma 1: L'Image-mouvement. Paris: Minuit, 1983.

Dennett, Daniel. “Are Dreams Experiences?.” Brainstorms: Philosophical Essays on Mind and Psychology. Cambridge, MA: MIT press, 1981. 129-148.

Gallagher, Shaun. Enactivist Interventions: Rethinking the Mind. Oxford: Oxford U.P., 2017.

Gerrig, Richard. Experiencing Narrative Worlds: On the Psychological Activities of Reading. New Haven: Westview, 1998.

Gottschall, Jonathan. The Storytelling Animal: How Stories Make Us Human. Boston: Houghton, 2012.

Herman, David. Story Logic: Problems and Possibilities of Narrative. Lincoln: U. of Nebraska P., 2002.

Herman, David. Basic Elements of Narrative. Malden, MA: Wiley-Blackwell, 2009.

Herman, David. Storytelling and the Sciences of Mind. Cambridge, MA: MIT Press, 2013.

Herman, Luc, and Bart Vervaeck. "A Theory of Narrative in Culture." Poetics Today 38.4 (2017): 605-634.

Hühn, Peter, et al., eds. The Living Handbook of Narratology. Hamburg: Hamburg University. Web. 12 Dec. 2019.

Iser, Wolfgang. The Act of Reading: A Theory of Aesthetic Response. London: Routledge, 1978.

Jannidis, Fotis. "Character." The Living Handbook of Narratology. Peter Hühn o. c.

Johansen, Joergen Dines. Literary Discourse: A Semiotic-Pragmatic Approach to Literature. Toronto: U. of Toronto P., 2002.

Krois, John Michael. "More than a Linguistic Turn in Philosophy: The Semiotic Programs of Peirce and Cassirer." SATS 5 (2004): 14-33. 
Lakoff, George. "The Neural Theory of Metaphor." The Cambridge Handbook of Metaphor and Thought. Ed. Raymond Gibbs. Cambridge: Cambridge U. P., 2008. $17-38$.

Liao, Shen-yi, and Tamar Gendler. "Imagination." The Stanford Encyclopedia of Philosophy (Winter 2019 Edition). Ed. Edward N. Zalta. Web. 12 Dec. 2019.

Liszka, James Jacob. A General Introduction to the Semeiotic of Charles Sanders Peirce. Bloomington: Indiana U.P., 1996.

Mar, Raymond A., and Keith Oatley. "The Function of Fiction is the Abstraction and Simulation of Social Experience.” Perspectives on Psychological Science 3 (2008): 173-192.

Miall, David S. "Affect and Narrative: A Model of Response to Stories." Poetics 17 (1988): 259-272.

Nünning, Ansgar. "Surveying Contextualist and Cultural Narratologies: Towards an Outline of Approaches, Concepts, and Potentials." Narratology in the Age of CrossDisciplinary Narrative Research. Ed. Sandra Heinen and Roy Sommer. Berlin: De Gruyter, 2009. 48-70.

Palmer, Alan. Fictional Minds. Lincoln: U of Nebraska P., 2004.

Peirce, Charles Sanders. The Collected Papers of Charles Sanders Peirce Vols. I-VI. Ed. Charles Hartshorne and Paul Weiss. 2, 3. Ed. Arthur W. Burks. Cambridge, MA: Harvard U.P., 1931-1935 \& 1958.

Peirce, Charles Sanders. The Essential Peirce: Volume 1 (1867-1893) and Volume 2 (1893-1913). Ed. The Peirce Edition Project. Bloomington: Indiana U. P., 1992 \& 1998.

Richardson, Alan. "Imagination: Literary and Cognitive Intersections." The Oxford Handbook of Cognitive Literary Studies. Ed. Lisa Zunshine. Oxford: Oxford U.P., 2015.

Ricoeur, Paul. Time and Narrative. 1. Chicago: U. of Chicago P., 1984.

Ricoeur, Paul. "The Function of Fiction in Shaping Reality." A Ricoeur Reader: Reflection and Imagination. Toronto: U. of Toronto P., 1991. 117-136.

Ryan, Marie-Laure. Possible Worlds, Artificial Intelligence and Narrative Theory. Bloomington: U. of Indiana P., 1991.

Ryan, Marie-Laure. "Possible-Worlds Theory." Routledge Encyclopedia of Narrative Theory. Ed. David Herman, Manfred Jahn, and Marie-Laure Ryan. London: Routledge, 2005. 446-450.

Sternberg, Meir. "Universals of Narrative and Their Cognitivist Fortunes (II)." Poetics Today 24 (2003): 518-638.

Walsh, Richard. "Dreaming and Narration." The Living Handbook of Narratology. Ed. Peter Hühn. o.c.

Zunshine, Lisa. Why We Read Fiction: Theory of Mind and the Novel. Columbus: Ohio State U. P., 2006. 


\section{Pripovedni svetovi in semiotična pravila pripovedne domišlijie: Peirce in Cassirer kot izhodišče za preučevanje izkustva sveta skozi literaturo}

Ključne besede: postklasična naratologija / kognitivna teorija / semiotika / pripovedni svet / domišljija / Peirce, Charles Sanders / Cassirer, Ernst

V pričujočem prispevku s pomočjo uvidov Peircea in Cassirerja umestim teorijo pripovednega sveta v širšo fenomenologijo pripovedne domišljije. Prvi korak je semiotični opis pripovedne domišljije; elementi zgodbe se uresničujejo skozi zakone, ki jih Peirce pripiše vsem semiotičnim procesom (razdelek 1). Peirceove uvide poleg tega uporabim za to, da pokažem, kako zelo se ti elementi razlikujejo glede na svojo bodisi fenomenološko ali epistemološko naravo. Iz opisa semiotičnih procesov nato izpeljem matrico devetih znakov (razdelek 2), ki ustrezajo devetim različnim načinom delovanja domišljije. Hipoteza je, da za ustrezen opis izkustva posameznega pripovednega sveta zadostuje, če vsakemu od devetih znakov pripišemo ustrezno funkcijo.

1.01 Izvirni znanstveni članek / Original scientific article

UDK 82.0-3

D0I: https://doi.org/10.3986/pkn.v43.i1.01 